\title{
Growth and Development of Telecom Sector in India - An Overview
}

\author{
Dr. Gopika.G.G* \\ *Lecturer, Department of Commerce and Management Studies, A.C.Kunhimonhaji Memorial I.C.A College.
}

\begin{abstract}
After the implementation of the Federal Financial Integration Scheme on $1^{\text {st }}$ April, 1950, the administration of the entire network of telegraphs and telephone systems of the nation, including those that previously existed in the former princely state became a major adventure. India had around 84000 telephone lines for its population of 350 million at the time of its independence in 1947. India is the fastest growing economy post its liberalization and globalization activism and Asia's third largest economy behind Japan and China. India's telecom density is not so high as compared to the western market. These liberalization measures introduced in the telecom sector were expected to boost the investors' confidence, bring greater competition for the benefits of subscribers and develop modern telecommunication network in the country at a faster pace. The rapid growth in Indian telecom industry has been contributing to India's GDP at large. After independence the growth in telecom sector in public sector was fair and well planned.
\end{abstract}

\section{Introduction}

Telecom is an essential infrastructure for economic development and hence for the improvement of the quality of human life. The use of telephone is in different activities like social and economic, and gathering information and knowledge. From these the highest use goes to social activities. It is used for saving time and expenditure in social and financial contexts. In India people are interested in owning mobile phones. The mobile telephone connection is costly when compared with land phone connections, as the initial capital cost of handset purchase is more. Salaried and business people who are having comparatively high economic status were the most intensive users of mobiles. In the absence of cheaper fixed line services mostly in rural areas, there are increased use of WLL phones and mobile phones. But in such cases there arise problems in the case of range also. As the desired inter locator is reached through telephony, and the telephone is likely to be the quick way for communication, telephone has a considerable advantage over other communication channel in emergencies. Simplicity in access makes telephony more particular in the case of priority requirement for all socio-economic groups.

The telecom services have been very much useful for promotion of employment. They create number of job opportunities in this new field. By the use of internet, doctors are getting consultancy from all over the world. One can interact with another and can receive important tips about a particular case from the experience of the other doctor. With the help of Telephone, producers and the middle men are able to gather information about the availability of raw material, market price and finished products. Telephone is considered as the means for obtaining and sharing information. Public Telephone facilities are useful to the poor also. It can replace the need to travel or postal costs. High level of use of telephone for Social networking implies that most of the rural areas are in need of subsidised access. Wider access to internet service is possible through the expansion of telecommunications connectivity. House holds in most contexts tend to spend, on average, between 2 per cent and 4 per cent of house hold income on telecommunications. The use of telephone for the acquisition of information and knowledge was very low till the introduction of availability of internet through phones.

Most of the developing countries are facing the growth phase of telecom sector, because of the technology changes in accordance with the local geography. At the primary stage the numbers of mobile phone connections are lower than the number of land phone connections in developing countries. After 1995 most of the developing countries are facing rapid growth in the cell phone penetration. While considering the technological development in the telecom sector, India is late starter. India is the fourth largest telecom market in Asia after China, Japan and South Korea. The Indian telecom network is the $8^{\text {th }}$ largest in the world and the second largest among the developing economies.

\section{Origin and Development of Telecommunication in India}

In the year 1851 the British first introduced telecommunication services in India through operational land lines near Kolkata. Dr. William O'Shaughnessy who pioneered telegraph and telephone in India belonged to the Public Works Department all through the experimental stage. Electronic telegraph made its appearance in India as early as in 1854. A regular separate department was opened around 1854 when telegraph facilities were thrown open to the public. Being a British Colony, both telegraph and telephones were introduced into 
India almost contemporaneously with United Kingdom. The telegraph department during1854-'57 comprised of a superintendent of telegraphs, with three deputy superintendents at Bombay, Madras and Pegu in Burma. There were inspectors at Indore, Agra, Kanpur and Banaras and an operating and maintenance staff. Indo-European Telegraph Department, which later came to be known as the overseas communication, was administered by a Director-in-Chief whose Head Quarters was in London.

In 1880, two telephone companies namely The Oriental Telephone Company Ltd. and The AngloIndian Telephone Company Ltd. approached the Government of India to establish telephone exchanges in India. The permission was refused on the grounds that the introduction of telephones was a Government monopoly and that the Government itself would commence the work. By 1881, the Government changed its earlier decision and eventually a license was granted to the Oriental Telephone Company Limited of England for opening telephone exchanges at Kolkata, Mumbai, Chennai and Ahmadabad. The telephone service was made operational in the year 1881. Telephone came to India in 1882, a little later. On $28^{\text {th }}$ January, 1882, Major E. Baring, member of Governor General of India's council confirmed the opening of Telephone exchange in Kolkata named "Central Exchange" and it carried 93 subscribers. The telegraph, and later the telephone were introduced in India in 1882 and were viewed by the British as tools of command and control that were essential to maintain law and order in the country. In 1883 the British combined the telegraph services with postal services to further increase there command and control in India. Runners, Stationed at telegraphs offices, carried telegrams to remote post offices, there by linking the British rulers with even the most distant pockets of India. Bombay also witnessed the opening of Telephone Exchange in 1887.

On $15^{\text {th }}$ February, 1888, the overseas communications was merged with the Director-General of the Indian Telegraph Department. It was decided that the administration reports of the two departments, Indian Telegraph and the Indo-European department, should be separated so as to show how the finance of the country were affected by each unit. The operations of the two separate services, Post Office and Telegraph Department developed side by side. On the eve of the first World War in 1914, the next big administrative change came. The Postal Department and the Telegraph Department were amalgamated under a single Director-General. The process had started in 1912, but completed in 1940. A major reorganization of the department took place in April, 1925. The accounts of the Indian posts and Telegraphs were reconstituted to examine the true fiscal profile of the department. The attempt was to find out the extent to which the department was imposing a burden on the tax payers or bringing revenue to the Exchequer, how far each of the four constituent branches of the department, the postal, telegraph, telephone and wireless were contributing towards this result. It was further examined whether the rates charged from the public for the various services were inadequate or excessive. The Posts and telegraphs, like all public and private undertakings, was a victim of the universal financial and economic depression which crashed on the world in 1930. During 1931, numerous economy measures had to be introduced according to the advice of the Posts and Telegraphs sub-committee to the Retrenchment committee presided over by Sir. Cowasjee Jahangir. Naturally the adoption of the various measures of retrenchment could not but have an adverse effect on the emoluments and interests of the personnel of the Department. From the beginning P \& T setup was run on welfare lines without the motto of profit. The annual report of the department for 1931 said, "It is the accepted policy of the government that the department should be so administered that there should be neither any substantial profit nor any substantial loss on its working under normal conditions". The department is bound by a large volume of statutory and other rules. After gaining independence from Britain in 1947, the national government continued the colonial legacy, organizing post and telegraph services exclusively in the domain of the state. Jawaharlal Nehru's post independence socialist policies dedicated India to state - run, state owned monopolies in various sectors, including Indian telecommunication as well. The foreign telecommunication companies were nationalized and the Posts, Telephone and Telegraph (PTT) Company was set up by the Ministry of Communications.

After the implementation of the Federal Financial Integration Scheme on $1^{\text {st }}$ April, 1950, the administration of the entire network of telegraphs and telephone systems of the nation, including those that previously existed in the former princely state became a major adventure. In 1950 the number of telephone exchanges absorbed from princely states was 196 . This system which was working with different degrees of efficiency could fit into the general telecommunication network. The installed capacity of these 196 exchanges was 13,362 lines with 11,296 working connections. Soon after the absorption an attempt was made to improve their technical efficiency by replacing absolute and unserviceable equipment and lending well-qualified and experienced staff. Isolated exchanges were integrated with the general pool. The more complicated task was accusation of the staff. Their final absorption into the different cadres of service in posts and telegraph was a major step. By April, 1972, the telecommunications accounts were separated. Simultaneously the department also started preparing the balance sheet annually.

In 1978 Telecom Consultants India was set up to discharge the responsibility of providing telecom services in foreign countries. The public sector units like the Indian Telephone Industries and the Hindustan Cables Ltd loss their monopoly positions. The Centre for the Development of Telematics (C-DOT) was 
established to promote research and development of indigenous technology in the field of telecom. By mid-80's, C-DOT also gave production rights for their RAX's up on payment of substantial fee to the private sector. Managed by slow-moving, over staffed government machinery under the aegis of the Ministry of Posts and Telegraphs, the performance of India's telecommunications sector was slow until the mid - 1980s. The main reason for this poor performance was with the view that telephones were a 'luxury' rather than a 'necessity'. Moreover, there was the dominance of the state - run telecommunications with no competitive pressures for originality in telecommunications product, services and their pricing. In India the Ministry of Posts and Telegraphs focused in improving the delivery of telegrams and telexes while other countries were embracing digital telephony and facsimile machines. Till $31^{\text {st }}$ December, 1984, the Postal Telegraph and Telephone Services were managed by the Posts and Telegraphs Department. In January 1985, two separate departments for the posts and the telecommunications were created. The accounts of the department, initially were maintained by the accountant general of the P \& T.

In India, telecom sector is one of the major sectors where there is more chances for its sustainable growth. The Indian telecom market ranks among the fastest growing industries in the country. Indian Telecom market is mainly divided in to two major segments namely, the Fixed Service Providers (FsPs) and the Cellular Service Providers. Fixed service provider network comprises land lines, basic services, domestic and long distance call service. The two major basic operators BSNL and MTNL comprise almost 90 per cent of the FSPS in the country around 5 per cent are operated by private firms and are mostly scattered in the urban areas. In most cases the private basic service telephone operators cater to offices, business firms, schools and the corporate sector. In the case of the cellular services there are mainly two subdivisions. They are CDMA and GSM. In the GSM sector, the major players are Vodafone, Airtel, Idea cellular, Aircel and so on. The national company BSNL also has its GSM service named "Cell one" which has a major share in the semi urban and rural areas. The major companies which dominate the CDMA Scenario are Reliance Communications and Tata Indicom. In both the sectors of cellular services, perfect competition exists according to the demand supply chains.

From the holistic point of view telecom industry can be divided into four sub-sets. They are:

(a) Network Infrastructure companies; Alcatel, Lucent, Cisco, Ericsson.

(b) Telecom service Providers; Bharati-Airtel, Vodafone, Idea, Reliance.

(c) Telecom Equipment Manufactures; Nokia, Motorola, Samsung.

(d) Telecom Solutions Providers; Tech-Mahindra, Aricent, IBM India, Wipro, Sasken.

In Indian telecom sector, the government has named each state as each circle. These circles are "Metro" and "A", "B" and "C". "C" zones are based on subscriber potential. "Metros" are Delhi, Mumbai, Chennai and Kolkata. Circle A - Maharashtra, Gujarat, A.P, Karnataka and Tamil Nadu. Circle B-Kerala, Punjab, Hariyana, U.P [East \& West], Rajastan, M.P and West Bengal. Circle C - Himachal Pradesh, Bihar, Orisa, Assam, and North East. Bombay and Delhi Telephones were separated to create the new entity called Mahanagar Telephone Nigam Ltd. (MTNL).

\section{Department of Telecommunications (DOT)}

In the year 1985, the DOT was set up to provide domestic and long distance telephone services. The telecom services have been recognized the world-over as an important tool for socio-economic development of a nation and hence telecom infrastructure is treated as a crucial factor to realize the socio-economic objective in India. Accordingly, the DOT has been formulating development policies and projects for the accelerated growth of the telecommunication services. The Department is also responsible for frequency management in the field of radio connection in close co-ordination with the international bodies. It also enforces wireless regulatory measures by monitoring wireless transmission of all uses in the country. The DOT has been the premier telecom service provider in India with its presents through the length and breadth of the country. The Department in 1986 reorganized the Telecommunication circles with the SSAs as basic units. It was implemented in a phased manner. With a view to deciding matters of policy, a separate telecom Board, named the Telecom Commission, was also setup. The telecom commission was constituted in 1989. The Telecom commission was set up by the government of India with necessary executive, administrative and financial powers to deal with various aspects of Telecommunications. The Commission has the DOT Secretary as its Chairman with Member (Services), Member (Technology), and Member (Finance) as its fulltime members. The part time members are Secretary (IT), Secretary (Finance), secretary (Planning Commission), Secretary (DOE), Secretary (Industries), and Secretary (IP \& P). But this again composed mainly of the officers of the DOT. In 1999, modification was brought to the policy. The DOT has a Public Grievances cell at Sanchar Bhavan, New Delhi, which receives various types of complaints related to telecom services and takes these up with the concerned service provider for redressal. 


\section{Industrial Assistance and Export Promotion}

The Industrial Assistance and Export Promotion group working in DOT for the telecom sector is responsible for the activities such as (a) assistance in formulation of Import and Export policies for the sector, Foreign Investment policies and procedures; (b) processing of applications for foreign investment and foreign technology; (c) matters relating to promotion of telecom exports including sponsoring of trade delegation, setting up of Indian pavilions in International Exhibition and organization of seminars; (d) examination of matters relating to customs and excise duties and other Direct and Indirect Taxes for the telecom sector; (e) assistance in matters relating to Trade and Industrial policies; and (f) assistance to various industrial units in the Telecom sector for implementation of their projects.

\section{Mahanagar Telephone Nigam Limited (MTNL)}

In the year 1986 on $1^{\text {st }}$ April, the government established MTNL and was incorporated as a limited company to manage \& control telecommunication services in the two metropolitan cities of Delhi \& Mumbai. The jurisdiction of the company comprises the city of Delhi and the areas falling under the Mumbai Municipal Corporation and Thane Municipal Corporation. MTNL was setup, because the telephones in big cities were so difficult that a mere Departmental undertaking could not run it. For cellular services, the company has the license to provide the service in Delhi including the peripheral towns of Gurgaon, Faridabad, Ghaziabad \& Noida and in Mumbai including Kalyan. The vision of the company is to provide world class telecom services at affordable rates and ultimately to become total solution provider in telecom sector. MTNL had enjoyed monopoly till 2000 in the two metro cities of Delhi and Mumbai, where it operates. Since then the private operators have started providing basic services in Mumbai and are expected to do the same soon in Delhi. Increased competition from private operators was expected during the tenth plan. To maintain its position as a major player in Mumbai and Delhi, MTNL envisaged to expand its cellular network in a big way during the tenth plan. Expansion of internet services and introduction of IT related services is another major element of company's overall strategy of growth and competition.

\section{Videsh Sanchar Nigam Limited (VSNL)}

In the year 1986 the government established VSNL for international telephone services (overseas communications). VSNL was corporatized in 1986. The corporatization process was not smooth and the consultants were given a very short time to prepare a report. The organizational structure of VSNL consisted of a chairman and MD, supported by a board consisting of five members - finance, planning, operation, human resources, commercial and network services. After corporatization VSNL has been structured as a single organization. Now the VSNL has been fully privatized.

\section{Corporatisation}

Telecom markets were liberalized and regulated world-wide. Competition and welfare enhancement were the main drivers behind liberalization of markets. This called for opportunities not only for new entrance but also for incumbents. Regulation should be strategically aimed at enhancement of general welfare without mutilating markets nor harming providers or subscribers. India is the fastest growing economy post its liberalization and globalization activism and Asia's third largest economy behind Japan and China. India's telecom density is not so high as compared to the western market. These liberalization measures introduced in the telecom sector were expected to boost the investors' confidence, bring greater competition for the benefits of subscribers and develop modern telecommunication network in the country at a faster pace. Many companies are easily attracted to the telecom sector and are interested in investing large amount which is good for both the telecom sector and the economy of the country. India's telecom market is the fastest growing investment pocket in the world.

\section{Telecom Regulatory Authority of India (TRAI)}

In the year 1997, the government setup the TRAI to provide a comprehensive telecom service in the country. With the entry of private sector in the provision of telecommunication services a need was felt to have an independent regulatory body. This requirement was indicated in the guide lines issued for entry of private sector in basic telecom service. Accordingly, TRAI was established in the year 1997 in pursuance of TRAI (ordinance) 1997, which was later replaced by an Act of Parliament to regulate the telecommunication services. The desired objectives of bringing about functional clarity, strengthening the regulatory frame work and the dispute settlement mechanism have been attained by bringing about a clear distinction between the regulatory and recommendatory functions of TRAI, by making it mandatory for Government to seek recommendations of TRAI in respect of specified matters and by the setting up of separate dispute settlement mechanism. 


\section{Bharath Sanchar Nigam Limited (BSNL)}

After finalization of various financial and HRD aspects, the business of running telecom operations throughout the country except in the metros of New Delhi and Mumbai, the service providing functions of the Department of Telecom Services (DTS) and DTO were transferred to the newly created company BSNL. The two newly carved out service providing Departments from the DOT, namely the Department of Telecom Services (DTS) and Department of Telecom Operations (DTO) were corporatized ahead of schedule and a Public sector company "Bharath Sanchar Nigam Ltd. (BSNL)" was given all the service providing functions performed by these two Departments w.e.f. October 1, 2000 and began its existence as a fresh entity. The creation of BSNL was expected to provide a level playing field, in all areas of telecom services, between government operators and private operators.

With the corporatization of the two service providing Departments Viz. DTS and DTO in to a PSU "BSNL", the role of Telecom commission has been changed. After shedding the direct responsibility of service providing functions of the DOT, Telecom commission was responsible for policy formulation, licensing, wireless spectrum management, administrative monitoring of PSUs, research and development and standardization, validation of equipment etc.

Some of the other development activities of telecom sector are the following;

\section{a. Opening up of National Long Distance Services}

As per the new Telecom Policy (NTP), 1999, the Government has opened the National Long Distance Service beyond the service area to the private operators without any restriction on the number of operators w.e.f $13^{\text {th }}$ August, 2000. The government has also issued guidelines for providing Licenses to Infrastructure ProviderII (IP-II) for the purpose of leasing/ renting out/ Selling end- to-end band width. No formal license is required for providing assets such as Dark Fibres, Right of way, Duct Space and Tower. They are only required to be registered as IP-I.

\section{b. Telecom Dispute Settlement and Appellate Tribunal (TDSAT)}

A separate dispute settlement body known as "Telecom Dispute Settlement and Appellate Tribunal" to adjudicate any dispute between a licensor and licensee, between two or more service providers, between a service provider and a group of subscribers, and to hear and dispose of appeals against any decision or order to TRAI, has been formally constituted with the appointment of chairperson and two members. The tribunal has become operational and started hearing cases.

\section{c. Strengthening of the Unit for Telecom- Economic Analysis}

The Telecom Commission created a Policy planning cell in the Economic Research unit to prepare discussion papers, policy papers on national and international issues relating to the telecom sector. The Economic Research Unit (ERU) in the Department of Telecommunications which is a multi-disciplinary unit consisting of economists, statisticians, engineers and financial experts, provides various inputs on technoeconomic issues relating to telecom policy formulation and planning. The ERU compiles and disseminates various data on techno- economic parameters relating to telecom sector. The unit provides telephone demand projections for basic services to the Telecom commission and all the circle heads. The projections cover the demand at the all India level, each telecom circle and metro telecom districts and all the stations with equipped capacity of 200 lines and above. It studies the trends in the investment by the private sector to provide various telecom services. The ERU also carries out various techno-economic studies on specific issues relating to telecommunications, apart from sponsoring studies on specific aspects. Accordingly, it has carried out technoeconomic studies on tariff related issues, call distribution pattern etc. and prepared a number of reports and policy papers. It has prepared Indian Telecommunication statistics during the period under report. The material for the pre- Budget Economic Survey on Telecommunication was also prepared. The Annual Report of the Department of Telecommunication is also co-ordinated and brought out by the unit.

\section{d. Manufacture of Telecom Equipments}

India is a major manufacturer of a wide range of telecom equipments. The total production of telecom equipments and cables in terms of value has increased from Rs. 3985 crores in 1992-93 to Rs. 8,300 crores in 1996-97 which further increased to Rs. 10760 crores during 1999- 2000. The Indian telecom equipment industry's revenues fell marginally to Rs. 1,13,188 crores in 2011-2012 from 1,14,133 crores in 2010-2011.

\section{e. Export of Telecom Equipments \& Services}

India has been recognized as a key supplier of products and technologies for rural telecom by international organization Viz and ITV. Vigorous efforts are being made to increase the exports of telecom equipments and services. 


\section{f. Virtual Private Net work (VPN)}

VPN is a private data network that provides connectivity within closed user groups Via public telecommunication infrastructure. Competition is likely to heat up in the VPN segment as DOT has relaxed the norms for private players.

\section{g. Public Telephones}

The Opening up of Public Telephone (PTS) at various places like Bus station, Railway station, thickly populated areas and business areas were occurred so as to satisfy the requirements of ordinary people. In the areas where the density of telephones was very low, PTS were opened. But the introduction of Mobile phones has decreased the use of PTS. At the initial stage the PTS were only within the hands of DOT, as a monopoly. But the liberalization policies and the subsequent privatisation policies have paved the way for the installation of PTS of private companies also. The installation of electronic exchanges with dynamic locking system have prevailed upon the prospective subscribers to use the STD and ISD facilities of their own and the use of PTS for STD /ISD facilities became very rare.

\section{h. Reduction of Excess Staff}

DOT provides basic service by drawing a pair of copper cables for each connection. But such cables become faulty in rainy seasons. Underground cables have comparatively less fault rate, excluding these seasonal changes, than the over head lines. But at the time of over head lines, the required number of permanent line staff and mass doors, was more. In the case of underground cables comparatively less permanent employees are required. In this case the digging jobs are done by petty contractors but the technologies like WLL and mobile, the initial investment is heavy.

\section{i. World-wide Interoperability for Micro-wave Access (WiMAX)}

WiMAX has been one of the most significant developments in wireless communication in the recent past. Since this mode of communication provides network access in inaccessible locations at a speed of more than $4 \mathrm{Mbps}$, it is expected to be a major factor in driving telecom services in India especially Wireless services. Thus it will lead to the increased use of telecom services, internet, Value Added Service (VAS) and enterprise services, WiMAX is expected to accelerate economic growth and assist in providing better education, health care and entertainment services. Aircel is the pioneer in WiMAX technology in India. The state owned player, BSNL, aims to connect 74,000 villages through WiMAX.

\section{j. Mobile Number Portability}

It is a standard where a customer wishing to port his/her number, is required to contact the donor to obtain a Port Authorisation Code (PAC) which he/she then has to give to the recipient. Once having received the PAC the recipient continues the port process by contacting the donor. This form of porting is also known as 'Donor-Led' and has been criticised by some industry analysts as being inefficient. It has also been observed that it may act as a customer deterrent as well as allowing the donor an opportunity of 'winning- back' the customer. This might lead to distortion of competition, especially in the markets with new entrants that are yet to achieve scalability of operation. To reduce their network deployment costs, many service providers are considering infrastructure sharing. It is considered having the advantages like improved service quality, increased affordability for customers, faster roll out of services in rural and remote areas, significant reduction in initial set up costs, lower operating costs for service providers and increased environmental aesthetics.

\section{k. Value Added Services}

VAS in telecommunication industry refers to non-core services, the core or basic services being standard voice calls and fax transmission including bearer services. The value added services are characterised as (a) not a form of core of basic service but adds value in total service offering; (b) standards alone in terms of profitability and also stimulates incremental demand for core or basic services; (c) can sometimes be provided as stand alone; (d) do not cannibalize core or basic service;

(e) can be add-on to core or basic service and as such can be sold at premium price; and may provide operational synergy with core or basic services. A value added service may demonstrate one or more of these characteristics and not necessarily all of them.

\section{Growth in Telecom Sector}

After the inception in India, over a period of 200 years, telecommunication has indeed grown by leaps and bounds to occupy an important position in the Indian economy today. Buoyed by the rapid surge in the subscriber base, huge investments are being made into this industry. There were around 200 million telephone lines in India which makes it the $3^{\text {rd }}$ largest phone network in the world after china, and the US. Today, the 
telecom market in India enjoys the highest growth rate in the whole world. The improvement in the standard of living and the development of infrastructure and connectivity are some of the main reasons for the significant growth of the telecom industry.

In order to capitalise the opportunity of meeting the subscriber needs in highly competitive market the operators have reduced the tariffs to attract subscribers with low purchasing power primarily in semi urban and rural India. Through the changing regulations and events, the Industry players are aiming to achieve acquiring new subscriber by expanding in semi urban and rural India, and selling more services to existing subscribers. Several steps were taken to improve the tele-density in the country. Targets of additional DSLs were enhanced. Intensive efforts are being made to cover more villages through VPTs. Private sector is being encouraged to provide telecom facilities at a faster pace. The progress made was reviewed by the Minister of Communication during the meeting held with circle heads and heads of SSAs.

India had around 84000 telephone lines for its population of 350 million at the time of its independence in 1947. The rapid growth in Indian telecom industry has been contributing to India's GDP at large. After independence the growth in telecom sector in public sector was fair and well planned. The country wide telecom net wok worth Rs. 80000 crores has been set up entirely through public investment. It had increased the number of telephones in the country from hardly 60000 in 1950 to 21 million in 1999 . The international telephone circuits increased almost seven fold from 1000 to 6600 in seven years from 1986 to 1993 . When the telecom developments of other countries are considered, it is apparent that the developments in India are not much better. There are not enough telephone lines in India. There were 7 million phones for a population around 900 million people. India provides larger number of new telephone connections per year. Between 1988 and 1998, the number of villages with some kind of telephone facility increased from around 27,316 to 300000 villages. Revenues of the DOT, the state- run telecommunications operator, increased from \$790 million in 1988 to 4.3 billion in 1998, simply a five- fold increase in 10 years. Though there has been a sharp expansion in the telecom network in the country both in the basic services and cellular mobile services and an impressive increase in the tele-density (number of telephone per 100 population) from a level of 0.60 per cent in 1990-91 to 2.86 per cent by $1999-2000$. In the mid-1999 the cellular penetration in the cities had reached about one million people even though there was sluggishness in the case of basic services. It was in 1994 the telecom sector was opened up to allow private operators to provide cellular telephony services. The telecommunication network of the public Sector (BSNL and MTNL) in India was one of the largest telecom networks in Asia. The equipped capacity of the public Sector operators was increased from 26.1 million in 1998-99 to 32.8 million lines at the end of 1999-2000. The total number of Direct Exchange Lines (DELs) during the same period has increased from 21.6 million to 26.5 million. As on January $31^{\text {st }}, 2001$, the equipped capacity reached a level of 36.7 million and DELs to about 30 million. In the year 2011 the equipped capacity is 546.32 lakh lines.

The remarkable feature of the expansion of telecom network in India is the rapid increase in cellular mobile subscriber base. A stunning 117 billion metered calls were made in India from the PCO in 1998. Up to the year 1998, the country could achieve a growth in tele-density of 1.92 per cent only. After 50 years, in 1998, tele-density was 1.94 per cent only. Annual plan of 2000-'01 and revised plan 1999-2000, Inter-alia, pay special emphasis on accelerated growth and early implementation of telecommunication facilities. Tele-density in India in the year 2000 was 2 per cent, was being targeted to increase up to 7 per cent in 2005 and 15 per cent in 2015 by the NTP 1999.

The tele-density in India is very low not only compared to those in the advanced countries but also compared to those in other developing countries like China ( 7.0 per cent) Malaysia (19.8 per cent) and Thailand ( 8.4 per cent). Therefore a quantum jump both in quantitative and qualitative terms is required for expanding the telecom network within a shortest possible time to bring it at par with the rest of the world and achieve the largest enunciated by the NTP, 1999. During the first ten months of the financial year (2000-01), the subscriber base has further gone upto 3.27 million, a further increase of about 74 per cent. By 1999, India had an installed network of more than 25 million telephone lines that spread across 300 cities, 4869 towns, and 310897 villages, making India's telecommunications network the ninth largest in the world. The financial year 2002-'03 was a year of excitement and challenges for the Indian telecom industry. The industry witnessed significant regulatory developments along with changes in the competitive landscape. The year witnessed the introduction of interconnect usage charge and a free mobile incoming regime for the first time in India. This interconnect regime has attempted to bring about a level playing field while trying to put an end to predatory and discriminatory practices.

India is the fastest growing free market democracy in the world. It has a mature and dynamic private sector, which accounts for 75 per cent of India's GDP and a market with enormous potential due to its large size and diversity. India offers significant business opportunities to the services, as well as the manufacturing sectors. This is because India offers benefits such as cost advantage in product development and back- office processing and the large scale availability of skilled professionals. The middle class population is also a significant market for any business entity. The target for the $11^{\text {th }}$ plan period (2007-12) is 600 million phone 
connections with an investment of US $\$ 73$ million. Apart from the basic telephone service, there is an enormous potential for various value added services.

Competition deregulation and technological revolution continue to change the way of telecommunication sector functions. India added 130 million new customers in 2008-'09, the largest globally. The country's cellular base witnessed close to 50 per cent growth in 2008 , with an average 9.5 million customers added every month. Massive investment running into billions of dollars (installing each telephone line costs about \$750) were needed for the expansion, so private sector involvement intensified. Indian Telecommunications portrays the real sense of transferring the information between two distant points in space. Thus the history of Indian telecom can be started with the introduction of telegraph and still ongoing with the present status of effective mobile phones available all over the country.

The telephone coverage in India rose to 34.50 per cent in Jan, 2009 from 33.23 per cent in December 2008 , indicating huge market potential, especially in rural areas, the cell phone subscribers increased 10.81 millions in December 2008 and 15.40 million in January, 2009. Up to the end of January, 2009, the total number of cell phone subscribers in India had reached 362.3 millions, the fixed phone subscribers dropped to 37.75 million from 37.9 million in December 2008, and the broadband subscribers increased to 5.65millions from 5.45 million. During the month of March 2009 BSNL added a net of 1,17,000 land line connections registering a positive growth after several years of steep and steady dips. As per the Telecom subscription data as on $31^{\text {st }}$ August, 2009, the number of telephone subscribers in India increased to 494.07 million at the end of August, 2009 from 479.07 million in July 2009. In the wireless segment there are 15.08 million new additions. There has been a substantial decline in tariffs over the years. The adoption of new technology has been a major factor that has helped service providers reduce the tariffs considerably. As per the accounts on $31^{\text {st }}$ March 2011, in BSNL there are 90 million subscribers (27.45 million wirelines, 72.69 million wireless lines), 1,32,243 crore asset, 2,81,635 employees and BSNL has $6^{\text {th }}$ position in mobile connection, 6,000 crores loss in 2010- 2011. Although there has been a rapid rollout of cellular mobile networks with over 886.0 million subscribers as on June 2011, there has been relatively less penetration in rural areas with only 298.1 million connections. Besides huge gap between rural and urban tele-density, broadband penetration. The Indian telecom market is expected to grow by Rs. 3,44,921 crores by the year 2012. The rate of growth will be around 26 per cent and the sector will also generate employment to around 10 million people. The number of telephone subscribers is expected to grow by around 650 million.

The statistics in the history of Indian telecommunication show that there has been a mammoth revolution in this sector of India. The continuing growth of the telecom industry seems to have become a key contributor to India's progress. Today, there are about 500 million telecom subscribers with a net addition of more than 11 million new mobile subscribers per month.

\section{Foreign Direct Investment in Telecom Sector}

India is the fastest growing free market democracy in the world. India's emergence as a leading destination for foreign investment is considered as the result of stable economic outlook, large market potential, large talent pool, and low labour cost. In the view of policy-makers regulators, a conducive and competitive climate for foreign investment can facilitate the capital investment required for building telecom infrastructure.

The Indian telecom industry has always allured foreign investors. In fact, the cumulative FDI inflows from August 1991 to March 2007, in telecommunication sector amounted to US \$. 7513.22millions. This makes telecommunication the third largest sector to attract FDI in India in the post liberalization era. The investment was majorly in handset manufacturing and telecom services. With stable macro-economic impetus and numerous other advantages, India has the potential to become the electronic manufacturing hub of the world. With the world now recognizing India's manufacturing potential, the Indian telecom handset manufacturing market is likely to touch a huge amount in the coming years.

The following table shows the development \& growth of telecom sector in India.

\begin{tabular}{|l|l|}
\hline Year & Details \\
\hline November 1850 & The first Experimental Electric Telegraph line was started between Calcutta and Diamond Harbour. \\
\hline October 1851 & The Telegraph line Completed and opened for East India Company's traffic \\
\hline April 1852 & $\begin{array}{l}\text { Dr. O' Shanghnessy's report on Success for working of the experimental line landed before the } \\
\text { Bengal Govt. }\end{array}$ \\
\hline October 1854 & The first Telegraph Act enacted. \\
\hline February 1855 & Electric telegraph opened to public traffic \\
\hline January1856 & First Indo- European telegraph communication effected \\
\hline 1857 & The 'Mutiny' Electric Telegraph saved India' - Dalhousie. \\
\hline 1858 & First Indo- Ceylon cable laid \\
\hline 1867 & A new cable laid between India and Ceylon \\
\hline 1871 & International Telegraph Conference at Berne and Rome \\
\hline October 1872 & Interference to Telegraph Working by Magnetic Storm \\
\hline 1873 & Duplex Telegraphy introduced in India between Bombay and Calcutta ,.Indigenous manufacture of \\
\hline
\end{tabular}




\begin{tabular}{|c|c|}
\hline & cables for river crossing by Telegraph Workshops, Alipore \\
\hline August 1875 & The first Private Telegraph line supplied by the Telegraph department \\
\hline August 1877 & $\begin{array}{l}\text { Indian Telegraph Department erected telegraph line between Srinagar and Gilgit on behalf of the } \\
\text { Maharaja of Kashmir }\end{array}$ \\
\hline July1880 & $\begin{array}{l}\text { I.T.D. transferred responsibility of the Ceylon Telegraph system and offices to the Ceylon } \\
\text { Government }\end{array}$ \\
\hline November 1881 & $\begin{array}{l}\text { Licenses granted to private Companies to operate Telephone Systems at Madras, Bombay, Rangoon, } \\
\text { Calcutta }\end{array}$ \\
\hline 28-1-1882 & $\begin{array}{l}\text { First Telephone exchange in Mumbai using Law's call wire equipment commissioned by Mumbai } \\
\text { Telephone company at fort. }\end{array}$ \\
\hline October 1885 & $\begin{array}{l}\text { Upper Burma Campaign- I.T.D helps in providing communications for swift advance. Introduction of } \\
\text { Quadruples telegraphy and copper wire for transmission }\end{array}$ \\
\hline 1886 & Copper wire for transmission between Bombay and Madras instead of iron wire \\
\hline 1887 & Facilities afforded to Indian Meteorological Service for communicating' Storm Signals' to all places \\
\hline 1888 & Post office and Telegraph Department combined as quasi - commercial department \\
\hline $1892-1893$ & All exchanges converted into Magneto Exchanges \\
\hline $1892-95$ & Construction and control of Telegraph System of Kashmir State by I.T.D \\
\hline $1895-96$ & Phonograms introduced for the first time at Bombay and Calcutta. \\
\hline 1896 & Introduction of phonogram at Mumbai \\
\hline 1902 & First wireless telegraph station was established between Saugor Islands and Sandheads. \\
\hline 1903 & $\begin{array}{l}\text { Field Telegraphs for Sikkim, Tibet, Reorganization of Superior Establishment in Telegraph, } \\
\text { Department Wireless Telegraphs introduced }\end{array}$ \\
\hline 1904 & Wireless Telegraph introduced between Elephant Point and Amherst. \\
\hline 1905 & $\begin{array}{l}\text { Control of Telegraph Department transferred from P. W. D to Commerce and Industry Department, } \\
\text { except for matters connected with Buildings and Electricity. }\end{array}$ \\
\hline 1906 & Baudot system introduced between Calcutta and Bombay, and Calcutta and Rangoon. \\
\hline $1906-1910$ & Underground cables introduced \\
\hline August1907 & Central Battery working of telephones was first introduced in Kanpur. \\
\hline December1907 & Women signalers employed for the first time. \\
\hline $1907-08$ & $\begin{array}{l}\text { Wireless Telegraph working between Diamond Islands and Port Blair were successful during the } \\
\text { nights of cold weather. }\end{array}$ \\
\hline 1908 & Wheatstone working between London Madras and Rangoon. \\
\hline 1909 & $\begin{array}{l}\text { Wireless Telegraph Traffic was maintained with ships at-sea from Calcutta stations at Diamond } \\
\text { Island and Table Island. }\end{array}$ \\
\hline $\begin{array}{l}\text { April } \\
1910\end{array}$ & $\begin{array}{l}\text { Birth of Technical Branch as a separate organizations for dealing with the technical matters under } \\
\text { Electrical Engineer-in-chief. }\end{array}$ \\
\hline December1910 & Telegraph Department awarded a gold medal in the United Provinces Exhibition held at Allahabad. \\
\hline $1910-11$ & Introduction of Circle Scheme in the department and decentralization. \\
\hline $1912-14$ & $\begin{array}{l}\text { Amalgamation of Postal and Telegraph Department under a single Director-General. Reversion of } \\
\text { control of P\&T again to P.W. D. }\end{array}$ \\
\hline 1913-14 & First automatic exchange at Simla with a capacity of 700 lines with 400 actual connections. \\
\hline 1914-18 & Production of war materials by Workshops. \\
\hline April1919 & Lady operators employed in Simla Exchange. \\
\hline 1920 & Madras-Port Blair route for Wireless Telegraph opened. \\
\hline $\begin{array}{l}\text { May } \\
1921\end{array}$ & $\begin{array}{l}\text { Recurrence of Magnetic storm after a period of } 50 \text { years. Telegraphs Traffic in south India } \\
\text { interrupted. }\end{array}$ \\
\hline August1921 & National Cash Registers introduced in Calcutta C. T. O. for the first time. \\
\hline 1921 & $\begin{array}{l}\text { Auto Exchanges were opened for the first time in India, Continuous wave transmitters for wireless } \\
\text { telegraphy replaces the spark transmitters, Introduction of R. A. X at Poona }\end{array}$ \\
\hline 1922 & Department erected a line for Tibetan Government from Gyantse to Lhassa. \\
\hline 1923 & $\begin{array}{l}\text { Long distance dialing (90 miles) introduced between Lahore and Lyallpur. } \\
\text { First Trunk Telephone Circuit in Burma established between Rangoon and Pegu }\end{array}$ \\
\hline 1924 & Floods and cyclone interrupted Telegraph Traffic throughout India. \\
\hline $1^{\text {st }}$ April1925 & Accounts of the Department re-constituted on the basis of a full-fledged commercial unit. \\
\hline $1925-26$ & $\begin{array}{l}\text { Conversion of Delhi Manual system to Auto System. Delux telegraphs for greeting messages with } \\
\text { foreign countries introduced. }\end{array}$ \\
\hline $23^{\text {rd }}$ July1927 & $\begin{array}{l}\text { Radio-Telegraph started working between U. K. and India with important stations at Khadki and } \\
\text { Daund. The beam station at Kirkee and Dhond opened by Lord Irwin and greetings exchanged with } \\
\text { the King of England. }\end{array}$ \\
\hline 1932 & Automatic time announcing machine with disc records installed \\
\hline May1933 & $\begin{array}{l}\text { Radio-Telegraphs communications between England and India opened by India Radio and Cable } \\
\text { Communication Co. Special Trunk Exchanges was installed at Kirkee. }\end{array}$ \\
\hline December1936 & Indo-Burma Radio-Telephone service started functioning between Madras and Rangoon. \\
\hline $1936-37$ & Use of Trunk Lines for broadcasting programmes introduced \\
\hline 1937 & $\begin{array}{l}\text { Burma and Aden Telegraph Systems, which were a part of Indian } \\
\text { Deluxe Telegram with foreign countries introduced. }\end{array}$ \\
\hline 1938-39 & $\begin{array}{l}\text { Construction of short wave and medium wave wireless telegraph receivers in a number of stations } \\
\text { and direction finding stations at Gaya and Allahabad. }\end{array}$ \\
\hline 1940 & $\begin{array}{l}\text { Introduction of 'Urgent Private Inland Trunk Calls'. Overseas Telephone Service temporarily } \\
\text { suspended due to war conditions. }\end{array}$ \\
\hline 1942 & $\begin{array}{l}\text { Bombay Australian wireless Telegraphic service inaugurated, The Bombay Telephone Workshop was } \\
\text { taken over by the I.T.D. }\end{array}$ \\
\hline
\end{tabular}




\begin{tabular}{|c|c|}
\hline February 1942 & Bombay-China Wireless Service inaugurated. Training centre at Calcutta transferred to Jabalpur. \\
\hline $1942-47$ & $\begin{array}{l}\text { Telecommunication Development Scheme came into operation. A Telecommunication Development } \\
\text { Board was set up. }\end{array}$ \\
\hline 1943 & $\begin{array}{l}\text { The Jabalpur Telegraph Workshop started, The Bombay, Calcutta and Madras Telephone Systems } \\
\text { were taken over by I.T.D }\end{array}$ \\
\hline August 1944 & Bombay-New York Wireless Telegraph Services was commissioned into service. \\
\hline September 1944 & Second civilian outlet to U.K, Delhi and London Wireless Telegraphs Service inaugurated. \\
\hline 1947 & $\begin{array}{l}\text { India was represented at the important Atlantic City International Radio Conference, Direct } \\
\text { Telephone link to Kashmir and Assam, Sri. Sardar Patel launched Jalaprabha on Telephone Carrier } \\
\text { Channel and Wireless, Foreign Telecom companies nationalized to form PTT }\end{array}$ \\
\hline $1^{\text {st }}$ June 1949 & Introduction of Hindi telegram in Devanagari script. \\
\hline December 1949 & 'Own Your Telephone' Scheme inaugurated. \\
\hline 1949 & Wireless station commenced functioning at Srinagar. \\
\hline $1949-50$ & State Merger Scheme; the P\&T gradually took over the respective State P\&T Systems. \\
\hline January 1950 & $\begin{array}{l}\text { India-Afghanistan Wireless Telegraph Service inaugurated. Radio-Telephone Service between India } \\
\text { and Nepal inaugurated. }\end{array}$ \\
\hline May-June 1950 & Coastal Wireless Stations at Karwar, Ratnagiri and Mangalore started. \\
\hline October1950 & The Wireless Telephone Service between Indonesia and India opened. \\
\hline 1950 & Private Priority Telegram introduced, Own Your Telephone Exchanges' Scheme began to operate. \\
\hline December 1950 & 'Telegraph Wires (Unlawful possession) of 1950, Act was passed by Parliament. \\
\hline $1950-55$ & Step by Step stroger exchanges commissioned \\
\hline March 1951 & $\begin{array}{l}\text { The first Asian Games held at Delhi was conveyed by a direct Radio telephone service between India } \\
\text { and Japan. Innovation of Radio-Telephoto Service. }\end{array}$ \\
\hline June 1951 & Wireless Telegraph link to Moscow. \\
\hline July 1951 & Wireless Telegraph and Telephone link to Egypt. First Toll Cable : Delhi - Ghaziabad. \\
\hline September 1951 & Wireless Telegraph and Telephone link to Iceland. \\
\hline December 1951 & $\begin{array}{l}\text { Launching of S.S Jalapushpa of Scimdia Steam Navigation Company at Vizagapatam by Shri N.V } \\
\text { Gadgil from Bombay through telegraph link circuits. Wireless Telegraphs link to Thailand. }\end{array}$ \\
\hline Mar/Aug 1952 & Wireless Telephone link to Iran/Japan. \\
\hline 1953 & $\begin{array}{l}12 \text { channel carrier systems introduced, First Automatic Exchanges in Calcutta. Telex Service in } \\
\text { Bombay, First 12-Channel Carrier Systems. Introduction of Frequency Modulation. Mechanization of } \\
\text { Telephone Revenue Accounting, A12 channel carrier system was introduced in the nation }\end{array}$ \\
\hline $1956-1960$ & Central Disk tape recorder type announcement introduced \\
\hline July 1959 & First Coaxial route between Delhi-Agra commissioned. \\
\hline November 1960 & First subscriber trunk dialing route was commissioned between Kanpur and Lucknow. \\
\hline December 1965 & First microwave route between Calcutta-Asansol opened. \\
\hline $1966-70$ & Penta Conta Cross Bar Exchange installed for the first time in Mumbai \\
\hline February 1967 & First crossbar-local exchange commissioned at Mambalam-Madras. \\
\hline December 1967 & First crossbar trunk automatic exchange out into service at Madras. \\
\hline March 1975 & $\begin{array}{l}\text { First PCM system between city and Andheri telephone exchanges commissioned in Mumbai. } \\
\text { 'Advanced Level Telecom Training Centre' commenced training activities from Delhi to be } \\
\text { eventually shifted to its own campus in Ghaziabad. }\end{array}$ \\
\hline 1976 & $\begin{array}{l}\text { Installation of SPC gateway telex exchange and introduction of International subscriber dialed telex } \\
\text { service. First Digital Microwave System introduced in Calcutta Junction network, First digital micro } \\
\text { wave junction was introduced }\end{array}$ \\
\hline 1978 & $\begin{array}{l}\text { Introduction of Press Bulletin Service (PBS). 'Telecommunications Consultants India Limited' set up } \\
\text { in the public sector to provide consultancy services in telecommunications. }\end{array}$ \\
\hline $1978-79$ & C-400 Hitachi crossbar commissioned on 26-5-78 at Malabar Hill. \\
\hline 1979 & First optic fibre system for local junction commissioned at Pune. \\
\hline 1980 & First satellite earth station for domestic communications established at Secunderabad (U.P) \\
\hline 1980'sthe beginning & $\begin{array}{l}\text { Teledensity in } 1980-81-0.3 \text { per cent, Introduction of public pay phones, Private sector allowed, DOT, } \\
\text { MTNL and VSNL formed }\end{array}$ \\
\hline 1980 & First satellite earth station for domestic communications was established at Secunderabad \\
\hline 1981 & Troposcatter system link between India and U.S.S.R. inaugurated. \\
\hline 1982 & First SPC electronic digital telex exchange commissioned at Bombay. \\
\hline 1983 & First analog stored program control exchange for trunk lines was commissioned at Mumbai \\
\hline 1984 & $\begin{array}{l}\text { Centre for Development of Telematics (C-DOT) was established as a society for development of } \\
\text { digital switching system. C- DOT was established for indigenous development and production of } \\
\text { digital exchanges }\end{array}$ \\
\hline 1985 & $\begin{array}{l}\text { First Mobile Telephone Service introduced on non- commercial basis in Delhi. First Radio Paging } \\
\text { introduced in Delhi. }\end{array}$ \\
\hline $1985-1986$ & Navi Mumbai Telecom District formed on 1-4-85 \\
\hline 1986 & On 1-4-86 MTNL was formed and 'Videsh Sanchar Nigam Limited' was established. \\
\hline 1987 & First digital coaxial $140 \mathrm{Mb} / \mathrm{s}$ between Ahmedabad and Rajkot commissioned. \\
\hline $1987-88$ & Large Scale introduction of Push Button instruments \\
\hline 1988 & International gateway packet switch system commissioned at Bombay. \\
\hline $1988-89$ & Phone plus services introduced for subscriber number connected with Electronic exchanges. \\
\hline Early to mid 90's & $\begin{array}{l}\text { Telecom Policy 1994, Basic Telephony service to Private operators, } 49 \text { per cent FDI, } 8 \text { Licensees } \\
\text { began operations in August } 1995\end{array}$ \\
\hline Late 90’s & Birth of a regulator: TRAI, NTP 1999 (New Telecom Policy) \\
\hline 1991 & $\begin{array}{l}\text { I-Net exchange commissioned. Inmarsat costal earth station at ARVI to provide maritime } \\
\text { communication. Voice Mail Service (VMS) introduced in Delhi. }\end{array}$ \\
\hline
\end{tabular}




\begin{tabular}{|c|c|}
\hline 1994 & $\begin{array}{l}\text { Announcement of National Telecom Policy, Cellular telephone service started in Calcutta and Delhi, } \\
\text { Internet service provided by VSNL, ISDN service started commercially }\end{array}$ \\
\hline 1995 & $\begin{array}{l}\text { The "Telecom Regulatory Authority of India" was set up, Wireless in Local Loop (WLL) telephone } \\
\text { system introduced in MTNL. Delhi, Basic Telecom services opened for private competition }\end{array}$ \\
\hline $1995-96$ & $\begin{array}{l}\text { Usage of automatic number announcement service introduced. Interactive fault repair service } \\
\text { introduced. }\end{array}$ \\
\hline $1996-97$ & ISDN services introduced commercially. Auto com service introduced \\
\hline 1998 & New ISP policy was announced \\
\hline $1998-99$ & MTNL became an ISD \\
\hline 1999 & $\begin{array}{l}\text { The service providing arms of the DOT separated from the policy making and licensing function, A } \\
\text { new Telecom Policy was formulated, National Long Distance market thrown open for competition, } \\
\text { Wireless planning and co-ordination committee created to review and enforce spectrum allocation } \\
\text { policy, Lowered the license fee. The government changed the prevailing fixed annual license fee to a } \\
\text { revenue share regime, DOT is separated into two organs- DTS and DTO }\end{array}$ \\
\hline $1999-2000$ & MTNL Mumbai crossed the 2 million mark in subscriber base. MTNL became 100 per cent electronic \\
\hline 2000 & $\begin{array}{l}\text { Telecom disputes, settlement and Appellate Tribunal was established, National Long Distance } \\
\text { Service opened for private competition, Bharat Sanchar Nigam Limited is born on } 1^{\text {st }} \text { October. }\end{array}$ \\
\hline $2000-01$ & MTNL launched its GSM service under the Brand Name "Dolphin" on $27^{\text {th }}$ February, 2001 \\
\hline 2001 & $\begin{array}{l}\text { Convergence Bill to promote, facilitate and develop the carriage and content of communications } \\
\text { tabled in the parliament, Policy for GMPCS service has been announced, Policy for PMRTS has been } \\
\text { announced, Policy for UMS was announced }\end{array}$ \\
\hline $2001-02$ & MTNL got listed at New York Exchange on 6-11-2001. \\
\hline 2002 & $\begin{array}{l}\text { VSNL came under private management, International Long Distance Service opened for private } \\
\text { competition, Internet telephony was started }\end{array}$ \\
\hline $2002-03$ & $\begin{array}{l}\text { TRAI adjudged MTNL as "Best Telecom Service provider" Prepaid service under the Brand Name of } \\
\text { "Trump" has been launched simultaneously in Mumbai \& Delhi on 14-1-2002 }\end{array}$ \\
\hline 2003 & $\begin{array}{l}\text { Paved the way for a calling party pays (cpp) regime. Subscriber no longer had to pay for incoming } \\
\text { calls, making the mobile phone highly affordable to the low usage customers who mainly used it for } \\
\text { incoming calls. ( Inter connect usage charges regime), The termination charges made uniform for all } \\
\text { types calls- cellular mobile, fixed and WLL(m); Allowed an operator to provide fixed and / or mobile } \\
\text { service using any technology. (Unified License); The first phase of implementation, the unified } \\
\text { Access service license was readily adopted by most of the major operators. }\end{array}$ \\
\hline $2003-04$ & MTNL becomes No:1 in Internet Service provider in Delhi and Mumbai \\
\hline 2005 & $\begin{array}{l}\text { FDI } 74 \text { per cent, The per minute Access Deficit charge on domestic long distance calls reduced by up } \\
\text { to } 60 \text { per cent and the ADC on international calls by up to } 40 \text { per cent, Union Budget } 2003-04 \text { cut } \\
\text { the customs duties on telecom sector capital goods from } 25 \text { per cent to } 15 \text { per cent and on cell } \\
\text { phone's from } 10 \text { per cent to } 5 \text { per cent Union Budget } 2004-05 \text { exempted imports of capital goods for } \\
\text { manufacture of mobile handsets from customs. }\end{array}$ \\
\hline 2006 & $\begin{array}{l}\text { The per minute ADC for domestic calls replaced with a revenue share fee of } 1.5 \% \text { of non- rural (wire } \\
\text { line) AGR, coupled with a sharp } 60 \% \text { drop in per minute ADC on international calls. }\end{array}$ \\
\hline 2007 & $\begin{array}{l}\text { ADC on per centage revenue share reduced to } .75 \% \text { from } 1.5 \% \text { of AGR. Per minute ADC on } \\
\text { outgoing international calls reduced to zero, and on incoming international calls reduced to Rs. } 1 \text {, } \\
\text { Roaming rental reduced to zero. Reduction of roaming tariffs to the extent of } 22 \text { per cent }-56 \text { per cent, } \\
\text { Port charges reduced by } 23-29 \text { per cent }\end{array}$ \\
\hline $2007-2011$ & $\begin{array}{l}\text { Having the world's lowest call rates the fastest growth in the number of subscribers ( } 45 \text { million in } 4 \\
\text { months); The fastest sale of million mobile phones (in a week); The world's cheapest mobile handset; } \\
\text { The world's most affordable colour phone }\end{array}$ \\
\hline 2014 & Recommended by telecom regulator TRAI on spectrum sharing. \\
\hline
\end{tabular}

Source: Compiled from various reports and publications of DOT, BSNL and Govt: of India

\section{Conclusion}

India is a nation which is blessed with sufficient materials and manpower. But strong doubts exist about the optimum utilization of these resources. India is a country with population of more than one billion. The mobile Operators can catch the Indian rural markets with the provision of some incentives there as the rural market of India is very large as 70 per cent of the population lives there. Recent years have seen a tremendous growth in all facets of telecom services.

\section{References}

[1]. Selvaraj. V.M and Mrs. Ganesan Malathi: "A Study on Subscriber Behaviour Towards Cell Phone Users in Thoothukudi City", Indian Journal of Marketing, Vol. XXXv, No. 5, May 2005, page No: 23

[2]. Kala Seetharam Sridhar and Varadharajan Sridhar: "Telecommunication and Growth, Causal Model Qualitative and Qualitative Evidence", Economic and Political weekly, Issue No. 25, June 24, 2006.

[3]. Gamos Ltd: MC Komey Ki Scott N,etal: "Innovative Demand models for Telecommunications services", The report of an earlier KaR study, Gamos Ltd for DFID, 2003

[4]. David Souter, etal, "The Economic Impact of Telecommunication on Rural Livelihoods and Poverty Reduction", IIM (Ahmedabad).

[5]. op.cit. Kala Seetharam Sridhar and Varadharajan Sridhar: "Telecommunication and Growth, Causal Model Qualitative and Qualitative Evidence", Economic and Political weekly, Issue No.25, June 24, 2006.

[6]. K.R.G. Nair: "Telecommunications in India", Productivity, Vol: 36, No: 2 July - September, 1995

[7]. Floyd Eugene Alonzo III: Dissertation Abstracts International, Vol.64, No 8, February, Ph.D city University of New York, 2004 
[8]. Amod Gore, “Telecom”, Capital Market, Vol. XV/15, Oct-15, 2000.

[9]. http://eravandi.blogspot.com/2009/12/telecom-sector.html

[10]. Rekha Jain: "WLL, Governance, Corporatization, and Swansi- A Review of Institutional Developments", India Infrastructure Report, 2002, Oxford University Press, New Delhi.

[11]. DOT, Annual Report, 1999

[12]. BSNL, Annual Report, 2001

[13]. www.cybermedia,com

[14]. Anjana Prachi,etal: "Telecom Industry-Business Environment Domain Study", 2009, http//www.scribd.com,5.08pm, 6 ${ }^{\text {th }}$ January,2012.

[15]. DOT, Annual Report, 1992.

[16]. http://www.ey.com/IN/en/Industries/Telecommunications.

[17]. -"The Telecom Imbroglio", Monthly Comentary,Vol.XLI, No.1, August,1999.

[18]. Ibid

[19]. DOT, Annual Report, 1993

[20]. DOT, Annual Report, 1998

[21]. op.cit. BSNL, Annual Report, 2001

[22]. http://www.trai.gov.in/ntpt 1999

[23]. www.timesnow.tv

[24]. Consultation paper No: 7/2007, "Review of License Terms and Conditions and Capping of Number of Access Providers", Telecom Regularly Authority of India, New Delhi, June 12, 2007.

[25]. Vickram Crishna, Noor-ud-Din Baqai, Bhoop Raj Pandey and Fazlur Raman, "Telecommunication Infrastructure-A Long Way to go",Economic and Political Weekly, Issue No. 47, $20^{\text {th }}$ November, 1999.

[26]. Clifford Alveres: "Dial the Right Stocks", Intelligent Investor, August 9, 2000.

[27]. op.cit. BSNL, Annual Report, 2001

[28]. Op.cit. Vickram Crishna, etal. "Telecommunication Infrastructure- A Long Way to go", Economic and Political Weekly, Issue No.47, November $20^{\text {th }} 1999$.

[29]. http://www.researchand markets.com/reports/28867, "India Telecom Industry Report,2008."

[30]. Jogi.G.L: "Serious, Honest and Urgent Self Introspection Called for". Editorial, TESA FLASH, Vol. XXXVIII, No.4, April 2009.

[31]. “BSNL Status", DOT-News Bulletin, BSNL Pensioners' Association Kerala Circle, Vol.4, November 2011.

[32]. http:// www.ibef.org,2.19 pm January 9, 2012.

[33]. http : // www.eg.com/IN/en/Industries/Telecommunications

[34]. op.cit. Anjana Prachi,etal: "Telecom Industry-Business Environment Domain Study", 2009, http//www.scribd.com,5.08pm, $6^{\text {th }}$ January, 2012 